\title{
Publishing in Small Business Economics: An Entrepreneurship Journal
}

\author{
David B. Audretsch • Christina Guenther • \\ Adam Lederer
}

Accepted: 7 May 2021 / Published online: 8 June 2021

(C) The Author(s) 2021

Plain English Summary Publishing entrepreneurship research is not just important but challenging. Longstanding experts in the field can provide helpful advice. As borders between academic fields blur, research fields are increasingly global in their perspective, knowledge, and findings, thus enabling robust participation in research fields at a scale previously unimaginable. Drawing on the experience, insights, and perspectives of three seasoned editors, we try to reconcile the seemingly incoherent and inherent frustration experienced by researchers, on the one hand, with the very purposeful and self-aware process of at least one scholarly journal, Small Business Economics: An Entrepreneurship Journal, on the other, to provide guidelines and insights to aspiring authors in what they should consider in crafting their research for submission with the goal of publication.

D. B. Audretsch

Indiana University Bloomington, Bloomington, IN, USA

D. B. Audretsch

Department of Innovation Management \&

Entrepreneurship, University of Klagenfurt, Klagenfurt, Austria

C. Guenther $(\triangle)$

WHU - Otto Beisheim School of Management, Vallendar, Germany

e-mail: Christina.Guenther@whu.edu

A. Lederer

DIW Berlin, Berlin, Germany
In providing this sage council, the paper provides guidance to researchers on the process of publishing their results.

JEL classifications $\quad \mathrm{L} 26 \cdot \mathrm{M} 1 \cdot \mathrm{M} 2 \cdot \mathrm{M} 13 \cdot \mathrm{M} 20$. M2

\section{Introduction}

As if undertaking research were not challenging enough, authors typically find the publication process to be daunting, fraught with confusion and ambiguities. Globalization has rendered many, if not most, research fields to be global in their perspective, knowledge, and findings, which has enabled robust participation in research fields at a scale unimaginable just a few years ago. However, this same globalization, combined with the growing recognition worldwide that knowledge and ideas matter immensely, has also resulted in a concomitant increase in the rejection rates of submitted manuscripts. Researchers, both young and inexperienced, as well as their older and more seasoned counterparts, are bewildered by the seemingly inconsistent and unpredictable process of publishing their research. Aspiring authors, as well as those disappointed, would like to know why one paper was published but another found to be unsuitable.

The purpose of this paper is to reconcile the seemingly incoherent and inherent frustration experienced 
by researchers, on the one hand, with the very purposeful and self-aware process of at least one scholarly journal, Small Business Economics: An Entrepreneurship Journal, on the other, to provide guidelines and insights to aspiring authors in what they should consider in crafting their research for submission with the ultimate goal of publication. As the article makes clear, how and why Small Business Economics vets submissions is to identify and ultimately publish those papers most likely to add value to, and change thinking in, the scholarly field of entrepreneurship. While it certainly seems chaotic from the outside, it is anything but. We hope that this paper will provide aspiring researchers and authors with a guiding star in the turbulent seas of publication.

\section{The value proposition for publication}

The mandate for Small Business Economics: An Entrepreneurship Journal is to advance the scholarly field of entrepreneurship and small business by publishing articles that make a substantial and significant contribution to the literature. It is, of course, not possible to ascertain with certainty which submissions actually constitute a bona fide substantial and significant contribution to the literature. Such a judgement about the actual contribution and impact of any given paper can only be ascertained with certainty ex post but not ex ante. Thus, the de facto practice guiding the editorial decision process revolves around determining the potential of each submitted manuscript to add significant value to the scholarly literature. As Shepherd and Wiklund (2020, p. 371) wisely advise, the most fundamental guide for publishing is to "ensure your paper is relevant to entrepreneurship scholarship."

The process of assessing the potential impact on, and contribution to, the literature from each individual submission is fraught with uncertainty and asymmetries. The plethora of rejected manuscripts that ultimately went on to rank among the most impactful papers of all time is more than an urban myth. The famous "Lemons" paper, for which George Akerloff (1970) was awarded the Nobel Prize comes to mind, as does the Black-Sholes paper (1973), for which they were not only recipients of the Nobel Prize, but also served as the cornerstone for an entire field-finance (Gans and Shepherd, 1994).
Similarly, George Orwell's classic, Animal Farm, was repeatedly rejected by publishers on the grounds that, "It's impossible to sell animal stories in the USA" (Bernard, $1990^{1}$ ). Closer to home, Jay Barney lectures to large audiences about the multiple rejections suffered by his famous 1991 manuscript, which posits the resource-based view of the firm; subsequent to its acceptance and publication in the Journal of Management, it now ranks among the most cited papers of all time in management, strategy and entrepreneurship; indeed, it is one of the most cited papers in all of the social sciences. ${ }^{2}$

Thus, a key focus in orienting research, putting a manuscript together, and, ultimately, submitting to Small Business Economics is to make explicitly clear what exactly constitutes the main value added of the paper, or contribution, and to whom. The prevailing myth is that research is a solo activity, best left to the lonely scholar toiling alone in some lonely office. While research is certainly individual-driven, that same research can only have value when someone else responds with the gold standard of scholarship, "That is interesting." Translated into the language of scholarship, this is the universal stamp of approval that the research does, indeed, have intrinsic valueat least to someone.

Thus, the basic unit and starting point for valuing research is not the individual researcher, toiling diligently away in their inner research sanctum, but rather something larger, greater, and outside of themselves-the community. ${ }^{3}$ A community typically solidifies around a common research trajectory and involves some aspect of research that often draws on a broad spectrum of fields and other strands of research in the literature. The community interacts and shares a common vision and set of values, not just about a topic, themes, and methodologies, but also a sense of what exactly constitutes value in the research field, as well as in a dynamic sense-which new ideas in the field constitute value that will ultimately shape how the field develops over time.

\footnotetext{
1 Cited from Gans and Shepherd (1994, p. 166).

${ }^{2}$ Cited from personal correspondence with Jay Barney on April 21, 2021.

3 Nicholas Philipson, "Publishing in Academic Journals," Institute for Development Strategies, Indiana University, 2017.
} 
A community does not typically map one-to-one with a singular correspondence onto a particular journal. Rather, each community publishes research in multiple journals. Similarly, each journal, like Small Business Economics, comprises a locus of different, and in some cases, quite heterogenous and disparate communities.

It is erroneous to assume that the title of the journal reveals the most salient feature defining research published. To grasp what is published and ultimately valued by a journal, like Small Business Economics, one must ascertain a sense of the relevant communities forming the core identity of the journal. The academic discipline of economics is, of course, highlighted in our journal title. However, the actual communities participating in the journal play the primary role in the valuation of research and submitted articles. The communities participating in and, therefore, at the core shaping Small Business Economics principally comprise researchers and scholars focusing on entrepreneurship and small business.

There is also considerably more to a community than a common topic. It is the interaction among members that defines the community. Thus, research on the topic of entrepreneurship and small business, or any of the many more specific sub-topics, is published in a vast array of journals, spanning a broad spectrum of academic disciplines, ranging from sociology to management, economics, geography, psychology, international business, strategy, finance, to law. While the topic may be the same-entrepreneurship and small business-the various communities to which the research is adding value are considerably different. The topic and subject may be the same, even using identical methodologies and approaches, but each community has its own unique way of valuing different aspects of research. Thus, what constitutes substantial value added to one community, deemed to be an important contribution, is not necessarily true for other communities. Since each journal reflects a unique underlying locus of different communities, not all journals will value the same, identical manuscript equivalently.

For Small Business Economics, the community revolves around the academic field of entrepreneurship and small business. There is no academic disciplinary preference or bias, just as there is no particular methodological, national, regional, or industry preference-only that scholars find the manuscript to have the potential to contribute considerable value to those communities important to Small Business Economics. Of course, the locus of scholarly communities constituting Small Business Economics is neither evenly distributed across academic disciplines and fields, nor across national and regional contexts. Rather, the journal reflects the inherent values of those scholars and researchers shaping each community.

Thus, to say that Small Business Economics welcomes all types of research focusing on entrepreneurship and small business, without regard to underlying methodologic, geographic, or industrial context, is not the equivalent of saying that all types of research are valued equally and equivalently. Rather, it is those specific research trajectories at the locus of communities shaping the identity of Small Business Economics that prioritize and shape the valuation of any submitted manuscript and, ultimately, its prospects for impact on and significance for the literature.

To name and identify the specific communities underlying Small Business Economics is not trivial. From the ex post perspective, we can identify specific communities, along with their concomitant topics, themes, methodologies, and style of presentation that have already been published in the journal and shaped its historic identity. However, research and its communities are dynamic and constantly evolving. Yesterday's valued contribution may still be important today, but it can no longer be considered to add new value and constitute a new contribution. Thus, research communities are in constant motion, with topics, themes, methods, and styles, not to mention actual participants, coming and going. To identify those communities and where they are headed, as well as the constant emergence of new communities in an a priori sense, is virtually impossible. That is why we, at Small Business Economics, eschew the common practice of locking in specific topics, fields, national contexts, and methodologies by naming specific fields that are guarded, restricted, and protected by field editors. 
Similarly, there is no algorithm or rubric for the format of a submitted paper. Rather, US President Abraham Lincoln's response to the question of how tall he was, "Tall enough to reach the ground,"4 so it is also with Small Business Economics. We purposefully strive to recognize and prioritize new ideas, approaches, insights, and methods that may extend beyond the boundaries of the extant classifications and categories reflecting what may have been valued in the past, but not necessarily in the future. Just as entrepreneurship is a future-oriented field, at the core identity of Small Business Economics is a mandate to publish research that will be valued in the future and not just in the past.

What this means for interested authors is, that first and foremost, make explicit: (1) what was known and understood by the relevant research community prior to the submitted research and (2) how thinking should be changed and different as a result of the research undertaken in the paper under review. It is incumbent upon the author to explicitly identify the key literature or strand of literature for which their research adds value. Leaving it up to those involved in the review process places a heavy burden on the editors and referees to sift through volumes of literature to unravel why, if at all, the paper adds value. When faced with a manuscript whose contribution is shrouded in uncertainty, compared to the stacks of other submissions making explicitly clear how and why the manuscript adds value to the literature, the editorial decision tends to select the latter over the former.

This is not to say that methodology does not matter. Methodology, of course, matters tremendously. It is the methodology that yields credence to the claims, findings, and conclusions of the paper. Still, we must confess surprise and wonder at the frequency to which we find various aspects of the methodology prominently highlighted in the title of the paper. Why allocate precious words and ideas in the scarce space inherently limited by the most prominent aspect of a paper-its title - to aspects that do not revolve around the fundamental contribution of the paper? Should the paper be published because it utilizes data for a particular time span, national or regional context, or

\footnotetext{
${ }^{4}$ Richard Lederer, "Lincoln as Jokester," Saturday Evening Post. 2013, https://www.saturdayeveningpost.com/2013/06/ lincoln-jokes/ (last accessed April 13, 2021).
}

a particular empirical method, such as a structural model, qualitative analysis, panel econometric estimation, or case studies? In certain, exceptional cases, the answer may be affirmative. However, it is important for potential authors to realize that the unique and salient value added for most of the research communities comprising Small Business Economics is rarely a new methodological approach. More likely, the contribution is found in the new ideas, insights, and conclusions about entrepreneurship and small business emanating from the application of that methodology, rather than the methodology itself.

\section{Conclusion}

We should conclude by emphasizing that none of the above constitute explicit guidelines for publishing in Small Business Economics. Those guidelines can be conveniently found on the Journal's website. Rather, with the benefit of many years being involved, this is our own reflection about what and why Small Business Economics finds important and interesting, which perhaps will help future authors. As that same US President, Abraham Lincoln described democracy, "government of the people, by the people, for the people," so too can the valuation of manuscripts by Small Business Economics be viewed as "of the community, by the community, and for the community." Our voices are but several among many in what promises to remain a vibrant and intellectually thriving community of scholars of entrepreneurship and small business.

Funding Open Access funding enabled and organized by Projekt DEAL.

Open Access This article is licensed under a Creative Commons Attribution 4.0 International License, which permits use, sharing, adaptation, distribution and reproduction in any medium or format, as long as you give appropriate credit to the original author(s) and the source, provide a link to the Creative Commons licence, and indicate if changes were made. The images or other third party material in this article are included in the article's Creative Commons licence, unless indicated

\footnotetext{
5 Abraham Lincoln, Gettysburg Address, 1863, Library of Congress. https://www.loc.gov/exhibits/gettysburg-address/ exhibition-items.html (last accessed April 13, 2021)
} 
otherwise in a credit line to the material. If material is not included in the article's Creative Commons licence and your intended use is not permitted by statutory regulation or exceeds the permitted use, you will need to obtain permission directly from the copyright holder. To view a copy of this licence, visit http://creativecommons.org/licenses/by/4.0/.

\section{References}

Akerloff, G. (1970). The market for "lemons": Quality uncertainty and the market mechanism. Quarterly Journal of Economics, 84(3), 488-500. https://doi.org/10.2307/ 1879431

Barney, J. (1991). Firm resources and sustained competitive advantage. Journal of Management, 17(1), 99-120. https://doi.org/10.1177/014920639101700108

Bernard, A. (Ed.). (1990). Rotten rejections. Penguin Books.

Black, F., \& Scholes, M. (1973). The pricing of options and corporate liabilities. The Journal of Political Economy, 81(3), 637-654.
Gans, J. S., \& Shepherd, G. B. (1994). How are the mighty fallen: Rejected classic articles by leading economists. Journal of Economic Perspectives, 8(1), 165-179. https:// doi.org/10.1257/jep.8.1.165

Lederer, R. (2013). "Lincoln as jokester," Saturday Evening Post. https://www.saturdayeveningpost.com/2013/06/linco ln-jokes/ (last accessed April 13, 2021).

Lincoln, A. (1863). Gettysburg Address. Library of Congress. https://www.loc.gov/exhibits/gettysburg-address/exhib ition-items.html (last accessed April 13, 2021).

Shepherd, D. A., \& Wiklund, J. (2020). Simple Rules, Templates and Heuristics! An Attempt to Deconstruct the Craft of Writing an Entrepreneurship Paper. Entrepreneurship Theory and Practice, 44(3), 371-390. https:// doi.org/10.1177/1042258719845888

Publisher's note Springer Nature remains neutral with regard to jurisdictional claims in published maps and institutional affiliations. 